\title{
A HELIKOPTER FELSZÁLLÁSI ENGEDÉLYRE VÁR. KORONAVÍRUS, MAKROÖKONÓMIA ÉS OKTATÁS.
}

\author{
Helicopter awaiting clearance for take-off. \\ Coronavirus, macroeconomics and education.
}

\author{
DR. SÁRKÁNY PÉTER, főiskolai tanár \\ EDUTUS Egyetem \\ sarkany.peter@edutus.hu
}

DOI 10.47273/AP.2020.20.120-149

\begin{abstract}
ABSZTRAKT
Mivel a koronavírus-járvány okozta gazdasági válság jelentősen eltér az eddig ismert válságoktól, ezért kezelésének eszközei is jórészt különbözőek az eddig alkalmazott módszerektől. Más megoldásokra, eddig nem ismert módszerekre, vagy csak elméleti szempontból felvetett, de a gyakorlatban valójában nem kipróbált lépésekre lehet szükség. A tanulmány ezek közül néhány lehetőség felvázolására vállalkozik, felhívva a figyelmet ezek bemutatásának fontosságára a közgazdaságtan oktatása során.
\end{abstract}

Kulcsszavak: koronavírus, helikopterpénz, feltétel nélküli alapjövedelem, örökjáradék kötvény, kurzarbeit, digitális jegybank pénz

\begin{abstract}
The coronavirus pandemic and the ensuing economic crisis is significantly different from the crises we have known thus far, which means the methods required to remedy it are largely dissimilar to established approaches. It may require alternate solutions, methods yet to be discovered, or an approach which has been purely theoretical so far, but yet to be tested in practice. The purpose of this examination, therefore, is to present a select number of methods, pointing out the importance of introducing these options in teaching economics.
\end{abstract}

Keywords: COVID-19, helicopter money, basic income guarantee, perpetual annuity bond, reduced working hours, central bank digital currency,

\section{BEVEZETÉS}

Magyarországon már 2020 január végén létrehozták a Koronavírus-járvány Elleni Védekezésért Felelős Operatív Törzset, amikor még nem is volt fertőzött beteg nálunk. Az első regisztrált esetet március elején jegyezték fel. Néhány nappal később már megjelentek a 
COVID-19 koronavírus-járvány gazdasági hatásainak enyhítésére hozott azonnali intézkedések rendeletei. Tudható volt, hogy a járvány okozta gazdasági válság a gazdaság szereplőit nehéz helyzetbe hozza, mivel egyszerre okoz kínálati és keresleti sokkot a gazdaságban: sok ember állása kerülhet veszélybe, ezáltal jelentős jövedelemcsökkenés következik be náluk, visszaesik számos területen a kereslet, azaz a termelők (vállalatok, cégek, iparágak) megrendelési nagymértékben elmaradhatnak, visszaesik a gazdaság teljesítménye, beindulhat egy inflációs nyomás. És ha az állam hathatós ellenlépéseket kíván foganatosítani, akkor az az eladósodás mértékének emelkedésével fog járni.

A koronavírus-járvány okozta gazdasági válság számos tekintetben eltérő, összehasonlítva korábbi gazdasági válságokkal (Hardy-Szapáry, 2020; Madár, 2020), így kezelésének eszközei is jelentősen mások lehetnek, mint az előzőknél voltak. Más megoldásokra, eddig nem ismert módszerekre, vagy csak elméleti szempontból felvetett, de a gyakorlatban valójában nem kipróbált lépésekre lehet szükség.

Cikkemben ezen megoldásokból szeretnék néhányat bemutatni, egyrészt annak érdekében, hogy ezután remélhetőleg tisztábban láthatunk közöttük, és másrészt azért is, mert - úgy gondolom - a közgazdaságtan oktatásába is be kell emelni ezeket a fontos és aktuális lehetőségeket.

\section{KUTATÁSI MÓDSZERTAN}

A hazai és nemzetközi áttekintés a szekunder vagy „desk research” kutatási módszerekre támaszkodik (meglévő releváns dokumentumok, publikációk, statisztikai adatbázisok, online weboldalak átnézése, majd az így összegyüjtött adatok rendszerezése, szelektálása, elemzése). Ezt kiegészítették a primer információk megszerzését célzó szakmai mühelybeszélgetések is. A hazai és nemzetközi tapasztalatokra épülő elemzésekből levont következtetések a szerző saját szakmai véleményét tükrözi.

Mivel a tanulmány a koronavírus-járvány idején készült, amikor a publikációk szinte kivétel nélkül online módon voltak elérhetők, ezért a felhasznált szakirodalmi jegyzékben is döntően internetes elérhetőségű cikkek szerepelnek.

\section{A HAZAI GAZDASÁGÉLÉNKÍTÉS MONETÁRIS-FISKÁLIS LEHETŐSÉGEI A COVID-19 UTÁN}

A járvány hazai felbukkanása óta eltelt négy és fél hónap alatt, azaz a július közepéig tartó időszakban egy EU-s felmérés (Szücs, 2020) szerint a magyar válaszolók 43 \%-ának csökkent 
a jövedelme, $35 \%$-a vesztette el részben vagy teljesen munkáját, $22 \%$-uknak gondot okozott a hiteltörlesztés, és $20 \%$-nak az is problémát jelentett, hogy naponta rendes ételhez jusson.

Vagyis a legnagyobb gond az emberek és persze a gazdaság számára egyértelműn a nem elegendő kereslet/jövedelem volt. Mi jelenthet megoldást ebben a helyzetben? Például az, hogy a jegybanknak pénzt kell juttatni a gazdaságba.

\subsection{A "helikopter pénz"}

Egy lehetséges megoldás: a „helikopter pénz”. Az ötlet Milton Friedman amerikai közgazdásztól származik, aki az 1960-as évek végén ezzel kívánta megoldani a deflációval küzdő USA problémáját. (Friedmann, 1969) A lényeg: a jegybank közvetlenül az állampolgároknak (azok bankszámlájára) ad többletpénzt, megnövelve így a fogyasztást. Az egyszeri juttatásban minden állampolgár részesül, amit bármikor el lehet költeni. A helikopteres pénzosztás nem máshonnan elvont pénzekből történik, hanem új pénz teremtéséből.

A „helikopter pénz” ötlete időről-időre előkerül (például 2003-ban ajánlotta ezt az amerikai jegybank elnöke, illetve a 2008-as válság kapcsán is felmerült, vagy 2016-ban, amikor az Európai Központi Bank elnökét kérdezték erről a lehetőségről). A koronavírus által kiváltott gazdasági problémák újra felszínre hozták ezt a lehetőséget, és komoly viták alakultak ki az ötletröl. ${ }^{5}$

Vajon mennyiben más ez az ötlet, mint a monetáris politikában az utóbbi időkben egyre gyakrabban alkalmazott ún. mennyiségi könnyítés (quantitative easing = QE)? És mennyiben hasonló a két megoldás?

„A mennyiségi enyhítés tulajdonképpen pénznyomtatást jelent” (Helikopter pénz, 2017, oldalszám nélkül) - tegyük hozzá: valódi fedezet nélküli pénznyomtatást - ugyanis ilyenkor a jegybankok (például egy válsághelyzet leküzdésére) pénzt teremtenek, és ezt arra használják, hogy pénzügyi termékeket (állampapírokat, kötvényeket, stb.) vásároljanak a bankoktól és a befektetőktöl annak érdekében, hogy a hosszabb lejáratú hozamok csökkenjenek. Tehát a mennyiségi lazítás egy monetáris eszköz, amelyhez nem kapcsolódik közvetlen fiskális politikai lépés.

\footnotetext{
5 Tegyük hozzá, hogy az elmúlt években olyan kezdeményezések is napvilágot láttak, mint a QE for People (mennyiségi enyhítés az emberekért) közgazdászokat is magába foglaló mozgalma, amely azzal érvel, hogy a pénzhelikopterpénz módszere alkalmas lenne arra, hogy a pénzügyi rendszert megkerülve, közvetlen a háztartások kapják meg a pénzösszeget. (Kicsid, 2016; QE for People, évszám nélkül)
} 
Ezzel szemben a helikopterpénz egy összehangolt fiskális-monetáris élénkítés, hiszen (a pénzmennyiség növelése, azaz) a „monetáris enyhítés” után fiskális lépés következik be a pénz szétosztásával. ${ }^{6}$

A két megoldás esetén különbség az is, hogy amíg a mennyiségi lazítás közvetlenül nem növeli - igaz közvetetten igen - az M1-es pénzmennyiséget (mivel elektronikus formában jön létre), viszont a helikopter pénz közvetlenül emeli meg az M1-es pénz nagyságát. Ugyanakkor, mivel mindkét esetben megnő a monetáris bázis (vagyis a készpénz és a jegybanki tartalékok nagysága), így ez két fontos kérdést vet fel: emelkedik-e az államháztartás adóssága, illetve okoz-e ez inflációt? Mindkét kérdésben megoszlottak a közgazdászok véleménye a Portfolio.hu-n 2020. áprilisában-májusában lezajlott vitában, amelynek végső kicsengése az volt, hogy a „helikopter pénz” államadósság-növelő és inflációs-nyomással rendelkező eszköz.

Közismert, és a hagyományos makroökonómiában ${ }^{7}$ is tanított megállapítás, hogy a jegybank által fedezet nélküli pénz beáramoltatása a gazdaságba egyrészt (a kereslet megnövelésén keresztül) infláció gerjesztő hatással bír, másrészt magában hordozza a költségvetés túlköltekezési éhségének veszélyét. Éppen ezért - harmadrészt - a legtöbb országban (így hazánkban is) tiltott, és negyedrészt növeli az államadósságot. Vagyis úgy tünik, az ilyen lépés közgazdasági szempontból értelmetlen és kockázatos is.

Ez kétségtelenül így van normál gazdasági körülmények között. De nem a mostani válsághelyzetben, sem az 1929-33-as nagy gazdasági világválság idején. Nem véletlen, hogy mindkét esetben keresletösztönzésre volt/van szükség. ${ }^{8}$ Igaz a nagy világgazdasági válság alapvetően keresleti sokk jellegü volt, míg ma egyszerre tapasztalható a keresleti és a kínálati sokk jelenléte. Teljesen egyet lehet érteni azzal, hogy egy normál gazdasági helyzettől eltérően „most nem az összkereslet elszabadulása, hanem zuhanása jelenti a kihívást” (Bihari, 2020b,

\footnotetext{
${ }^{6}$ Ezt fogalmazta meg a Lehmann és Vonák (2020) szerzőpáros, és Dedák István (2020) is. Ugyanakkor van, aki úgy véli, a „helikopter pénz” a fiskális politika hatáskörébe tartozik. „Az egész müvelet nem több, mint fiskális expanzió, amit kötvénykibocsátással, azaz adóssággal finanszíroz a kincstár (amit aztán egy nap vissza kell fizetni)" (Sebestyén, 2020, oldalszám nélkül). Van, aki szerint jobb lenne a „,helikopter pénzt” közvetlen monetáris mennyiségi lazításnak nevezni, mert közvetlenül a fogyasztókhoz kerül (Németh, 2020).

${ }^{7}$ Egy korábban kissé elszigetelt, de a koronavírus kapcsán előtérbe került, ,nem hagyományos” megközelítés, a Modern Monetáris Elmélet szerint bizonyos feltételek teljesülése esetén tulajdonképpen az állam bármennyi pénzt nyomtathat. (Chohan, 2020)

${ }^{8}$ Nagyon találóan azt mondhatjuk: ,az elmúlt hetek intézkedéseit látva, ma mind keynesiánusok vagyunk”. (Samu, 2020, oldalszám nélkül) Közismert, hogy Keynes az állam keresletbővitésében látta a megoldást az 1929-33-as válság kapcsán.
} 
oldalszám nélkül). Nagyon sokan vesztették el állásukat, sok cég (időlegesen vagy véglegesen) bezárt, nehéz helyzetbe került, ezáltal sokak jövedelme lecsökkent, vagyis eleve visszaesett a makrokereslet. Nem beszélve ezen emberek, családok helyzetének rosszabbodásával, ami a társadalom számára nem igazán megengedhető.

Mindettől függetlenül, kétségtelen, hogy a „helikopter pénz” csak csökkentheti a problémákat, és nem tekinthető csodaszernek, emellett alkalmazásának hatékonysága is hagy kívánni valót maga után. Ennek bizonyítása elméleti és gyakorlati szempontból is alátámasztható.

Tudjuk, hogy a közgazdaságtudomány több „lehetetlen hármast” (trilemma) is ismer. Ezek lényege, hogy három cél közül rendre csak kettő érvényesíthető. Ilyenkor a döntéshozó mindig választásra kényszerül. A többnyire a Mundell-Fleming-modell ${ }^{9}$ felhasználásával bemutatott, a monetáris politika lehetetlenségi tétele tétel azt mondja ki, hogy az árfolyamok rögzítettsége, a jegybanki politika autonómiája (önálló kamatpolitika) és a tökéletes tőkemozgás (nyitott tőkepiac) megvalósítása egyszerre, egy időben nem lehetséges. Tehát teljesen elfogadható az érvelés, amely szerint „minél kisebb és nyitottabb egy gazdaság, annál inkább igaz lesz az, hogy a belső kereslet élénkítése elsősorban az importot növeli, rontja a külső egyensúlyt, és a keresletnek legfeljebb nagyon kis hányada jutna oda, ahová szánjuk, azaz a hazai vállalkozások és munkavállalók megsegítésére” (Kertész, 2020, oldalszám nélkül). És tegyük hozzá, azt sem tudhatjuk biztosan, hogy a teljes többletpénz eljut-e a reálgazdaságba, mivel elképzelhető, hogy annak egy részét megtakarítják, befektetik a szereplők. ${ }^{10}$

Mint említettük, „helikopter pénzről” akkor beszélünk, ha 1) az állam (pontosabban a jegybank) új pénzt teremt, és 2) azt osztja szét minden állampolgárnak. Ebböl következik egyrészt az, ha az állam meglévő pénzek átcsoportosításával ad pénzt, igaz mindenkinek, az nem „helikopter pénz”, hanem valamilyen juttatás, támogatás. ${ }^{11}$ Másrészt, ha a jegybank ugyan új pénzt teremt, de abból nem ad mindenkinek (csak például valamilyen jövedelemszint alatt élöknek, vagy valami módon nehéz helyzetbe került szereplőknek, stb.), azt sem tekinthetjük szoros

\footnotetext{
${ }^{9}$ A modell lényege, hogy tökéletes tőkemobilitás esetén a monetáris és fiskális politika hatékonysága a belső egyensúly megteremtésében eltérő, az adott ország méretétől (kis, nyitott vagy nagy, zárt ország) és árfolyamrendszerétől (rögzített, rugalmas árfolyamrendszer) függ. M. Fleming brit és R. Mundell kanadai közgazdász egy időben, de egymástól teljesen függetlenül jutottak hasonló elméleti megállapításokra.

${ }^{10} \mathrm{Az}$, hogy ez mennyire reális veszély, az abból is látszik, hogy „az a 80 millió amerikai, aki költségvetési forrásból kapott 1.200 dollárt az összeomló gazdaság megtámasztása céljából, jelentős részben részvényeket vásárolt ezen." (Kovács, 2020, oldalszám nélkül.)

${ }^{11}$ Valójában a későbbiekben tárgyalandó Feltétel Nélküli Alapjövedelem is ebbe a kategóriába sorolható.
} 
értelemben vett „helikopter pénznek”, hanem inkább „feltételhez kötött új pénz (célzott) szétosztásának".

Ezek alapján valódi, feltétel nélküli „,helikopter pénzt” a mostani válságnál (Előd, 2020; Fellegi 2020) csak Japán esetében beszélhetünk, ahol minden állampolgár egy adott összeget kapott az államtól. USA-ban és Hongkongban az alacsony jövedelemmel rendelkező állampolgároknak adtak jövedelmet. ${ }^{12}$ Több országban (így például Olaszországban) bizonyos ágazatokban dolgozók kaptak támogatást. A legtöbb országban - Dániában, az Egyesült Királyságban, Csehországban, Lengyelországban, Németországban és Magyarországon is - adott feltételek megléte esetén a munkavállalók fizetésének valamennyi \%-át az állam adta meghatározott ideig. ${ }^{13}$ Izraelben egyszeri pénzjuttatást ígértek július közepén az állampolgároknak.

Tehát az országok - egy kivétellel - feltételhez kötötték a gazdaság szereplőinek nyújtott támogatást. Ugyanakkor az a gondolat, hogy „,adjunk pénzt mindenkinek”, újra előhozta a már többször előkerült, néhány országban bevezetésre is került, de sok sikert nem mutató „feltétel nélküli alapjövedelem" problematikáját.

\subsection{Feltétel nélküli alapjövedelem}

A feltétel nélküli alapjövedelem (röviden: FNA, angolul: basic income guarantee, vagy citizen's income vagy unconditional basic income, illetve hazánkban elterjedt megfogalmazással: LÉT-pénz) egy gazdaságpolitikai eszköz, a társadalombiztosítás olyan javasolt rendszere, melyben a politikai közösség összes tagja (azaz minden állampolgár14), egyéni alapon és feltétel nélkül rendszeresen fizetett jövedelemre jogosult. (Sheahen, 2015) Az ötlet nem újkeletü, mivel már a 16. században Morus (Szent) Tamás javasolta, hogy biztosítani kell minden embernek egy megélhetési alapot. Az elképzelést azóta is a világ sok országában - köztünk hazánkban is - magukévá tették, és megvalósításáról, bevezetéséről eszmecseréket folytattak. És akadtak olyan országok, ahol a gyakorlatban is kipróbálták.

A feltétel nélküli alapjövedelem öt fontos jellemzővel rendelkezik:

1. Az összeget pénzben (és nem természeti javakban) kapják az érintettek.

2. Egyénileg (és nem háztartásonként vagy nem családonként) jogosult rá mindenki.

3. Az érintettek rendszeresen (és nem egyösszegben) kapják.

4. Összege az alapvető szükségletek (étkezés és lakhatás) költségeire elegendő.

\footnotetext{
12 Július 26.-án jelentettek be egy újabb 1200 dolláros támogatást az amerikai állampolgárok számára. (Ma jöhet, 2020; Jöhet 2020).

${ }^{13}$ Erről a megoldásról - amit leginkább kurtzarbeitnek neveznek - még részletesen lesz szó.

${ }^{14}$ Van olyan javaslat, hogy csak a felnőttek kapjanak, illetve csak a munkanélküliek. (Pogátsa, 2019).
} 
5. A közösség minden tagja feltétel nélkül (és nem rászorultság vagy munkavállalási hajlandóság miatt) jogosult rá.

Sokszor azonosnak tekintik a feltétel nélküli alapjövedelmet és a garantált minimumjövedelmet, illetve a garantált bérminimumot.

A garantált minimumjövedelem (röviden: GMJ, vagy másképpen: államilag garantált minimális jövedelem, angolul: guaranteed minimum income) azt a célt szolgálja, hogy senki se keressen kevesebbet egy meghatározott szintnél. Tehát ez egy állam által müködtetett, jövedelem-újraelosztási rendszer, amelynél a jogosultságot bizonyítani kell. Amennyiben valakinek ez alatt van a jövedelme, akkor az állam kiegészíti azt a minimális szintig. Ez az eszköz annyiban tér el az FNA-tól, hogy nem feltétel nélküli, mivel összege függ a rászorultságtól, illetve az egyéb jövedelmektől. Bár az országokban különbségek mutatkoznak a fő célok, a kiterjesztettség és a rendszer müködtetése tekintetében, azért mindenhol a legfontosabb cél, hogy minden állampolgár vagy család a megélhetéshez elegendő jövedelemre tegyen szert. Ilyen minimális jövedelem az EU számos országában létezik.

Hazánkban 2006 óta alkalmazzák a törvényben rögzített garantált bérminimum rendszerét. Az erre való jogosultsághoz két feltételnek szükséges együttesen érvényesülnie. Egyrészt a munkavállalónak rendelkeznie kell középfokú végzettséggel, szakképzettséggel, másrészt a munkakör betöltése középiskolai végzettséghez, illetőleg középfokú szakképesítéshez legyen kötve. Tehát itt egy törvényi elöírásról van szó, amelynél a munkáltatónak kell - a feltételek megléte esetén - az összeget a munkavállalónak fizetnie.

Visszatérve a feltétel nélküli alapjövedelem kérdéséhez, rengeteg érv és ellenérv hozható fel bevezetésével kapcsolatban. Mivel ezek teljes kifejtése messze túlmutat a jelen cikk lényegén, ezért itt és most csak a legfontosabbakat, a legjellemzőbbeket említeném meg.

Az FNA mellett érvelők szerint ennek bevezetésével jelentősen lehetne enyhíteni a meglévő jövedelmi és vagyoni egyenlőtlenségeken, a gazdasági bizonytalanságon és komoly lépést lehetne tenni a mélyszegénység megszüntetése érdekében. Ugyanakkor szerepet játszhatna a gazdaságélénkítés megvalósításában, hiszen vásárlóerőt, kereslet- és termelésbővítést jelenthet a gazdaság számára. És mindenképpen meg kell említeni, hogy lehetővé tenné a kiszolgáltatott rétegek, szegregált csoportok elérését, ez pedig erősítené a különböző osztályok közötti szolidaritás érzését. Az érzelmekre ható legfontosabb érv pedig az, hogy mindenkinek joga van a szociális biztonsághoz, az emberi méltósághoz, amit az FNA elősegítene. 
Amennyiben az alapjövedelmet ellenzők véleményét tekintjük, akkor talán az első két legfontosabb érv, hogy az FNA nagy valószínüséggel inaktívitásra vagy szürkegazdaságba való átlépésre ösztönözne, illetve csak a jelenlegi összes juttatás (nyugdíj, munkanélküli járadék, állami egészségbiztosítás, stb.) átcsoportosítása nem lenne elegendő a finanszírozásra, így bevezetése a szociális kiadások megnövekedését jelentené, ami adónövelést tenne szükségessé. Félő, hogy a vásárlóerő-növelés inflációt gerjesztene a gazdaságban, és a jövedelmi-viszonyok jelentős javulása sem következne be. Mivel az európai országokban egyszerre történő bevezetése nem lehetséges, ezért nagy valószínüséggel a migrációs folyamatok felerősödését is magával hozná.

Az FNA-t (vagy annak némileg módosított változatát) hosszabb-rövidebb ideig, de mindig csak részlegesen számos ország próbálta ki:

1968 és 1982 között az Egyesült Államok kormánya 4 különböző negatív jövedelemadó ${ }^{15}$ tesztprogramot valósított meg, különböző államokban. Hasonló megoldással próbálkoztak Kanadában 2017 áprilisában. Az Alaska Permanent Fund 1982 óta évente fizet osztalékot minden jogosult alaszkai állampolgárnak. Hasonló megoldásként egy amerikai indián törzs tagjainak a területükön müködő kaszinó nyereségének egy részét feltétel nélkül, félévente szétosztják.

- FNA tesztprogramot valósítottak meg Kanada egyik városában 1975 és 1977 között, Srí Lankán a 2000-es évek elején (igaz nem állampolgároknak, hanem mikro vállalkozásoknak), Észak-Ugandában 2008-ban, Namíbiában 2008-tól ezer főre, Indiában 2009 és 2013 között.

$\square$ Különböző nemzetközi (karitatív) szervezetek pénzjuttatásokat adnak Kenyában 2008 óta, és adtak 2016-ban Libanonban. Iránban 2010 decemberétől adnak az állampolgároknak havi összeget.

- Európában egyedüliként Finnországban 2017 januárjában indítottak el egy kétéves kísérletet, amelynek keretében havonta 560 eurót juttattak kétezer, 25-58 éves, véletlenszerüen kiválasztott munkanélkülinek.

Az eddigi kísérletek eredményei ellentmondásosak, és a programok lassan megszüntek. Ennek ellenére az FNA-hoz, illetve a negatív jövedelemadóhoz hasonló programok vannak előkészületben Skóciában, Spanyolországban, Hollandiában, illetve az Amerikai Egyesült Államokban és Brazíliában. Svájcban is felmerült az alapjövedelem bevezetése, de az állampolgárok közel 4/5-e leszavazta az ötletet.

\footnotetext{
${ }^{15}$ A negatív jövedelemadó koncepciója lényegét tekintve nagyon hasonló, mint az alapjövedelem. M. Friedman és J. Tobin nevéhez köthető megoldás szerint az állam egy adómentes jövedelmi minimumot állapítana meg. Az ezen összeg feletti keresettel rendelkezők jövedelemadót fizetnének, míg a határ alatti jövedelmet eléröknél életbe lépne a negatív jövedelemadó, vagyis az állam kiegészítené keresetüket egy megállapított adókulcs szerint. (Friedman, 1967)
} 
Magyarországon nagyobb nyilvánosságot 2013-ban, Európai Unió tagállamaiban indult civil kezdeményezés hatására kapott e megoldás. 2014-ben egy részletes - a megvalósíthatóságot is bemutató - anyagot készítettek (LÉT, 2014), amit egy konferencia keretében mutattak be. Ennek hatására az ÉS (Élet és Irodalom) hasábjain 2014-ben folyt egy szenvedélyes vita. ${ }^{16}$ Először a Csillag és Mihályi szerzőpáros (Csillag-Mihályi, 2014a és 2014b) sorakoztatott fel számos - először 12, később 21-re kibővített közgazdasági - ellenérvet a LÉT-pénz hazai bevezetésével kapcsolatban adatokkal, tényekkel alátámasztva megállapításaikat. Ezután nagyon sok hozzászólás látott napvilágot - pro és kontra. Majd lassan elcsendesült a vita. Ugyan évente 1-2 írás megjelent a témában különösebb visszhang nélkül, azonban az elképzelés erőteljessé a koronavírus kapcsán kialakult válság hatására vált, amikor is a Városi Kurír 2020. március végén vitát indított el „Merre tovább?” címmel. A legelső javaslat szerint: „, Mindenki, aki tavaly legalább 3 hónap adózott jövedelemmel bírt, közmunkát végzett, KATÁ-s vállalkozása volt és még ki tudja milyen módon hozzá járult az ország fenntartásához, a válsághelyzet ideje alatt minden mástól függetlenül, havi 80.000,- Ft-ot kapjon az államtól. (Közmunkások a 48.000,- Ft-ot.)" (Surányi, 2020, oldalszám nélkül) A szerző létpénz-nek nevezi ezt a jövedelmet, amit csak ideiglenesen és adott feltétel teljesítése esetén kapnának meg az emberek. Így valójában ez nem nevezhető Feltétel Nélküli Alapjövedelemnek, inkább valamilyen átmeneti segély nyújtásának. Van, aki a minimálbér megemelését, és szociális minimáljövedelem (Szanyi, 2020), van, aki rendkívüli jövedelempótló támogatás (RJP) (Bokros, 2020a és 2020b) bevezetését javasolta. Van, aki meghatározott nagyságig egészítené ki mindenki jövedelmét, aki azt nem éri el. (Lendvai, 2020) Van, aki válságkezelő alapjövedelmet adna mindenkinek. (Kis, 2020) És újra előkerült Liska Tibor társadalmi örökség koncepciója ${ }^{17}$ is.

Érdekes és tanulságos annak áttekintése, vajon hogyan vélekedik a lakosság a feltétel nélküli alapjövedelem kérdéséről. 2014-ben, a LÉT-tanulmányának vitája után néhány nappal a Századvég Csoport 1000 véletlenszerüen kiválasztott felnőttkorú személyt kérdezett meg, és abból kiderült, hogy a magyar lakosság több mint kétharmada nem támogatja a LÉT munkacsoport által kidolgozott alapjövedelem-koncepciót. (A többség, 2014) (Az eredményt

\footnotetext{
${ }^{16}$ A vita kapcsán még sokan, sok más fórumon is kifejtették nézeteiket. A rengeteg hozzászólás részletes feldolgozása túlmegy jelen cikk keretein, és még inkább célján.

${ }^{17}$ Lásd: F. Liska Tibor (2020) és Liskáné Pólya Lenke (2020) tanulmányait. A „társadalmi örökség” alkalmazása azt jelentené, hogy születéskor mindenki kapna egy zárolt betétkönyvet, ,amiből fedeznie kell az egészségügyi ellátását, neveltetését, képzését, és ez szolgál induló tőkeként is a tanulmányok befejezése után, sőt ez a nyugdíj forrása is". (F. Liska, 1998, p.940)
} 
természetesen nagyban befolyásolta, hogy a pro és kontra érvek még nem voltak igazán ismertek az emberek körében.) 2020 áprilisában a világjárvány kiteljesedésekor történt megkérdezésnél már megfordult a lakossági megítélés, hiszen a Republikon Intézet 1000 fös (nem, életkor, végzettség és településtípus szerint reprezentatív) kutatása szerint ,az alapjövedelem bevezetésével a válaszadók túlnyomó többsége, 76\%-a egyet ért, az ellenzők aránya pedig 17\%-os. A kérdésről láthatóan kiforrott véleménye van a hazai társadalomnak, hiszen a megkérdezettek csupán 7\%-a nem tudott vagy nem akart válaszolni a kérdésre.” (Az alapjövedelem, 2020, 2) Hasonló eredményt mutatott ki a Pulzus Kutató 1000 fős reprezentatív közvéleménykutatása is, ahol a válaszolók $80 \%$-a az általános alapjövedelem bevezetését szorgalmazná, ezen belül 53 százalék szerint ezt a lehető leghamarabb meg kellene lépni. (Domokos, 2020). 2020 márciusában az Oxfordi Egyetem Szent Antal Kollégiumának Európai Kutatások Központja (Ash, 2020) az EU 27 tagállamára és Nagy-Britanniára kiterjedően több mint tizenkétezer, 16-69 év közötti állampolgárt kérdezett meg - többek között - az alapjövedelemről. Kiderült, hogy mindegyik korcsoport egyértelmüen (70\%-os mértékben) támogatná a bevezetését. Elgondolkodtató, hogy a kötelező európai minimálbér támogatottsága ennél is nagyobb, $85 \%$ körüli volt. ${ }^{18}$

Sokan vélekedtek úgy, hogy a koronavírus kapcsán kialakult válság megteremti a lehetőséget a feltétel nélküli alapjövedelem bevezetéséhez. Ahogy említettük, sok országban folytak viták ezzel kapcsolatban, és több ország is gondolkodik az alkalmazásáról, de úgy tünik - a válság lecsengése, gyengülése - az FNA témáját is elhalványítja. Ugyanakkor nagyon sokan (Ingyen, 2018; Márton, 2018; Sárosi, 2020) gondolják úgy, ez az eszköz nem fog eltűnni a közeljövőben, mivel a technika felgyorsult folyamata, a mesterséges intelligencia és a robotok megjelenése, az automatizáció következtében munkahelyek tömeges megszünése várható. Ez azt jelenti, hogy az embereknek más típusú, más képzettséget igénylő munkát kell majd végezniük, és az erre való átállás, átképzés időszakára is megélhetést kell biztosítani számukra. Ezt szolgálná akkor az FNA bevezetése.

\footnotetext{
${ }^{18}$ Csak az érdekesség kedvéért említem meg, hogy az FNA-ról a Makroökonómia tantárgy keretében 2020. áprilisában (még a járvány kirobbanásának kezdetén) megkérdeztem a hallgatók véleményét. Elmondva az alapjövedelem lényegét, azt kértem tőlük, hogy még aznap - anélkül, hogy utána olvasnának a témának - írják le saját véleményüket arról, egyetértenének egy ilyen rendszer hazai bevezetésével vagy sem, és indokolják is álláspontjukat. A semmilyen szempontból nem reprezentatív, és csak 60 főre kiterjedt megkérdezésböl kiderült, hogy mind a levelezős, mind a nappalis hallgatók kb. 2/3-a elutasította az FNA hazai alkalmazását.
} 


\subsection{Kurzarbeit, azaz a rövidített munkaidö támogatások}

Az, hogy az automatizáció ténylegesen kikényszeríti-e a feltétel nélküli alapjövedelmet, azt majd a (közel)jövő dönti el. Viszont a feltételesen és kifejezetten válsághelyzetben, vagy nehéz helyzetben adott támogatás már régóta jelen van a gazdaságokban. A Német Birodalomban már 1910-ben, később 1924-ben és aztán az 1950-es, sőt az 1960-as és 1970-es években is hoztak törvényt a csökkentett munkaidős dolgozók állami támogatásáról, amit németül kurzarbeitnek (angolul: short-time working-nek) hívnak. Az állami bérkiegészítés ezen rendszere igazán népszerüvé a 2008-as válság idején vált, és széleskörü alkalmazása a koronavírus-járvány hatására kialakult gazdasági nehézségek idején következett be. (Will, 2020)

„A módszer egyszerü: gazdasági visszaesések idején a cégek hazaküldhetik a munkavállalóikat vagy jelentősen csökkentheti munkaidejüket, miközben az állam átvállalja bérük nagy részének kifizetését" (Komócsin, 2020, oldalszám nélkül). A munkavállaló szempontjából az előny az, hogy nem veszíti el munkahelyét, és bére sem csökken túlzott mértékben, miközben nem dolgozik teljes munkaidőben, sőt rövidebb időszakokban semennyit sem. A munkáltató oldaláról előnyként jelentkezik az, hogy a válság csökkenésekor nem kell időt, energiát és pénzt költenie a korábban elküldött dolgozóik pótlására, azaz megtarthatják a már betanított és a szervezetben jól teljesítő dolgozóikat. Az állam szempontjából fontos pozitívum, hogy nem nő olyan mértékben a munkanélküliek száma (aránya) ${ }^{19}$, valamint a munkanélküli segélyek és az átképzéshez kapcsolódó kiadások mértéke, nem beszélve az állampolgárok részéről tapasztalható kedvező megítélésről.

Egyébként az Európai Unió már áprilistól pozitívan állt a csökkentett munkavégzéshez kapcsolódó támogatások kérdéséhez, hiszen a munkahelyvédelmi (SURE) program keretében a tagállamok támogatást hívhatnak le bizonyos, a rendkívüli helyzetekben foganatosított intézkedések költségeinek fedezésére, és ezek között vannak a Kurzarbeit típusú intézkedések is.

Most is sok európai ország gyakorlatában megtalálható volt, igaz „nem mindenhol ugyanazokra az ágazatokra vonatkozik, valamint egyes helyeken csak a karanténba kerültek kapnak állami

\footnotetext{
${ }^{19}$ „A 2008-2009-es pénzügyi válság idején bevált ez a megoldás: miközben Németországban 7,9 százalékról 7 százalékra csökkent a munkanélküliségi ráta 2009-en, az OECD országok átlagában három százalékról 8,6 százalékra ugrott. Az OECD becslése szerint 2009 harmadik negyedévében, amikor dühöngött a világgazdasági válság, 200 ezer munkahelyet tudtak megvédeni a németek ezzel a módszerrel.” (Komócsin, 2020, oldalszám nélkül)
} 
bérpótlást, másutt mindenki, aki most nem tud dolgozni a koronavírus hatásai miatt" (Sipos, 2020, oldalszám nélkül).

Nézzük néhány ország tényleges gyakorlatát a kérdésben (Hardi-Szapáry, 2020; Komócsin, 2020; Marton, 2020; Orban, 2020; Petrus, 2020; Sz.A., 2020; Véget, 2020):

Németországban a korábbi kereset 80\%-át (gyerekkel rendelkező munkavállalók esetében 87\%-át), de max. 3000 eurót kapnak 12 hónapon át. Ausztriában a rövidített munkaidő legalább 10, de legfeljebb 90\% lehet, míg időtartama nem lehet több, mint 3 hónap. Az Egyesült Királyságban a vállalatok folyamodhatnak állami támogatásért dolgozóik bérére, ami akár a fizetések 80 százalékát is fedezheti. Hasonló mértékü támogatás van Franciaországban, Svájcban, Svédországban is. Spanyolországban az ERTE rendszerben a felfüggesztett dolgozók fizetésük 70 százalékát kaphatják meg ideiglenes támogatásként. Csehországban a teljes bér 80\%-ára jogosultak, ha az iskolák és óvodák bezárása miatt gyermekükre kell vigyázniuk és ezért nem tudnak munkába menni. Egyébként munkahiány esetén az állam a bér 60 százalékát kifizeti. Dániában, Hollandiában, Írországban és Norvégiában a teljes bért fizeti az állam. Belgiumban és Spanyolországban 70\%-ot ad az állam. Olaszországban az iskolák, óvodák bezárása miatt gyerekeikkel otthon maradó szülők megkapják az államtól bérük 50 százalékát. Szlovákiában a kijárási korlátozások miatt kinyitni nem tudó vállalkozások alkalmazottainak bérét 80 százalékban átvállalta a kormány. Lengyelországban csak a 250 vagy annál több alkalmazottat foglalkoztató cégek, tehát a nagyvállalatok kaphatnak bértámogatást. Románia március közepétől május végéig segélyezte a felfüggesztett munkaszerződésű (azaz a kényszerszabadságra küldött) alkalmazottakat. Viszont június végén bejelentették, hogy az ország a napi gyakorlatba kívánja átültetni a rugalmas munkaprogram bevezetését rendkívüli helyzetek esetén.

Magyarországon április elején vezették be a csökkentett munkaidős foglalkoztatottak támogatását, amelyet az érintettek véleményének figyelembevételével két héten belül módosítottak. ${ }^{20}$ A támogatás elnyerésének feltételei között szerepel, hogy a munkáltatónak bizonyítania kell, hogy a munkavállalók megtartása a folyamatos gazdasági tevékenységével

\footnotetext{
${ }^{20}$ Lásd a 105/2020. (IV. 10.) és a 141/2020. (IV. 21.) számú Kormány rendeleteket!
} 
összefüggő nemzetgazdasági érdek. A támogatás mértéke alapesetben a korábbi bér $70 \%$-a, de maximum 3 hónapos időtartamra. ${ }^{21}$

Az OECD július közepén közzétett jelentésében nagyon hatásosnak ítélte meg a rövidített munkaidő-támogatás rendszerét. Példaképpen Németországot és az USA-t említette, ahol az előbbinél relatíve kis mértékben nőtt a munkanélküliség a járvány miatti válság következtében, míg az USA-ban (ahol nem minden tagállamban müködtettek ilyen rendszert) kiugró mértékben nőtt a munkanélküliség. (Rengeteg, 2020)

\subsection{Digitális jegybankpénz}

A fentiekben vázolt bármelyik keresletélénkítő, a gazdaság szereplőinek közvetlenül nyújtott támogatási megoldást müködtetik, érdekes kérdésként merül fel: vajon hogyan kellene az összeget eljuttatni az érdekeltekhez? Készpénzben? Bankszámlára utalva? Vagy másképpen?

2020 márciusában két amerikai elemző (Coronado-Potter, 2020a és 2020b) azt javasolta ${ }^{22}$, hogy a ma létező bankrendszeren kívül jöjjön létre egy speciális szolgáltató (amelyet Digital Payment Provider-nek neveznek), ahol minden16 évnél idősebb amerikai magánszemély számlát nyithatna. Ez a szolgáltató a FED és az amerikai pénzügyminisztérium engedélyével digitális dollárt bocsátana ki, amely bármikor beváltható lenne a hagyományos amerikai dollárra. Az újfajta pénzre azért lenne szükség, mert ha meghatározott időn belül nem költik el meghatározott javakra és szolgáltatásokra, akkor a pénz eltűnik a számláról.

A digitális jegybankpénz (angolul: central bank digital currency, röviden: CBDC) a jegybank által kibocsátott és ellenőrzött, dematerializált (tehát fizikai formában nem létező), univerzálisan hozzáférhető olyan digitális fizetőeszköz, amelynek árfolyama megegyezik a hagyományos fizetőeszközzel. Ez a pénz kiegészíti és nem felváltja a meglévő pénzügyi rendszer elemeit, emellett pedig a monetáris politikai célok elérését is támogathatja. A CBDC biztonságosabb, olcsóbb, földrajzilag és társadalmi csoportok szerint tágabb körben elérhető lehet, mint a hagyományos pénz.

A digitális jegybankpénz felépítése lehet számla (account) alapú, illetve érme (token) alapú. Struktúráját tekintve a digitális jegybankpénz két modellje ismert: lehet egyszintü (amikor a

\footnotetext{
${ }^{21}$ A 2020. augusztus 31-ig igényelhető bértámogatást május végéig 9500 cég igényelte, ami 125 ezer munkavállalót érintett. (CsD, 2020). Július közepei adatok szerint 14 ezer vállalkozás nyújtott be támogatási kérelmet 200 ezer munkavállalóra. (Már kétszázezer, 2020).

${ }^{22}$ Később az amerikai Szenátus egy tagja terjesztett be törvénymódosítást a digitális dollárról, illetve a digitális tárcáról.
} 
központi bank közvetlen kapcsolatban áll a gazdasági szereplőkkel), és többszintű (amikor a központi bank pénzügyi közvetítők szolgáltatásit veszi igénybe a digitális pénz szolgáltatásainál). (Szabó-Kollarik, 2020; Szegő, 2020b)

Bár vannak hasonlóságok a kriptovalutákkal, de a digitális jegybankpénz nagyon más. A kriptovaluták a digitális valuták egy részhalmazát képviselik, de besorolhatók az alternatív valuták vagy a virtuális valuták csoportjába is. Olyan csere- és fizetőeszközök, amelyek titkosítást használnak a tranzakciók biztonságossága érdekében. A kriptovaluták tranzakcióinak tárolása blokklánc technológiával történik, ami nyilvános (bárki csatlakozhat), elosztott fökönyvi technológiát jelent, és amelynél így az adatokat nagyon nehéz módosítani, megváltoztatni. A kriptovaluták általában decentralizáltak, azaz központosított testület helyett különböző összetételű online közösségek tartják ellenőrzés alatt.

A digitális jegybankpénz egyrészt elveti a virtuális valuták monetáris rendszerét, másrészt központi testület (a jegybank) tartja ellenőrzés alatt, nem pedig online közösségek. Tehát a legfontosabb különbség az, hogy mennyire és hogyan használja fel a pénzt a monetáris politika, illetve ki, mikor és hol férhet hozzá a szolgáltatáshoz. Ezeket a digitális jegybankpénznél a központi bank határozza meg, míg a kriptovalutáknál nem.

Valójában négy tényezőben összegezhető, hogy miért nőtt meg, és gyorsult fel az igény a digitális jegybankpénzek iránt:

- „A digitális pénz és digitális értéktovábbító szolgáltatások iránti kereslet az elmúlt években jelentősen megnőtt. Ez a tendencia várhatóan jelentősen erősödni fog a COVID19 és ahhoz hasonló járványok megjelenése következtében. Természetesen léteznek online pénzügyi szolgáltatások, azonban ezek nagy része a papír alapú pénz koncepcióját próbálják jól-rosszul digitalizálni és nem természetes (native) módon digitálisak.

- Technológiai "nyomás": A blokklánc és kriptovaluta tízéves fejlődése következtében eljutott arra a szintre, hogy általánosan is használatos digitális pénz rendszereket lehessen vele megvalósítani. Lassan a digitális jegybankpénzre is reális technológiai alternatíva lehet. Ráadásul, mivel blokklánc témakörben szinte teljesen open source, az egyik legdinamikusabban fejlődő értéktovábbításra alkalmas technológia.

- Az üzleti szektor kezdi felismerni a piaci igényt és a technológiai lehetőségeket, amelynek eredményeként olyan szolgáltatások jelennek meg, amik versenytársai lehetnek a jegybankpénznek is. Ilyen projektek például a stabil kriptovaluták, vagy a Facebook Libra projektje. 
- Végül de nem utolsó sorban fontos tényező a versenyfutás a több jegybankkal. Amelyik először vezet be nemzetközileg is elfogadott digitális jegybankpénzt, jelentős előnyre tehet szert." 23

Az Egyesült Államokkal szemben - úgy tünik - Kína lépéselőnybe került, hiszen közel áll ahhoz, hogy bevezesse a központi bank által kibocsátott digitális jüan-t. (Mészáros, 2020) Egyébként Kínán kívül más országok - így Svédország, Kanada, Uruguay, Szingapúr, Thaiföld és Bahamák - is kísérleteznek, vagy tesztelnek digitális jegybanki pénzeket. Sőt Hollandia felvetette, hogy szeretnének egy európai digitális pénz „,próbaterülete” lenni. (Huszák, 2020) Franciaország pedig korábban azt tervezte, hogy 2020-ban elindítja az állami kriptovaluta tesztelését. (2020-ban jön, 2019)

Az MNB elnöke szerint „évtizedünk az eddigi pénzügyi innovációk forradalmi felgyorsítását hozhatja” (Matolcsy, 2020, oldalszám nélkül), és közeleg az idő a digitális jegybankpénzek megjelenésére.

Tehát digitális pénzpiacra, és annak szabályozására mindenképp szükség van. Nemcsak a fent említett folyamatok következtében, hanem annak ismeretében is, hogy például egyrészt saját digitális devizát bocsáthat ki 2020 második felében a japán Mitsubishi UFJ Financial Group, a világ ötödik legnagyobb bankja (Virtuális, 2020), és másrészt Németország március elején a világon elsőként minősítette a legnépszerübb digitális pénznemet, a bitcoint hivatalosan is pénzpiaci eszközként. (Rácz, 2020)

\section{5. Örökjáradék kötvény}

Térjünk vissza egy kicsit a helikopterpénz ötletéhez! A helikopterpénz nyújtása esetén elképzelhető, hogy a központi bank hitelszerződés nélkül engedi át a kormányzatnak a létrehozott helikopterpénzt. Így nem is lesz visszafizetési kötelezettség. De az is lehet, hogy a hitelszerződésben lejárat kerül megállapításra, csak a kormány nem akar, vagy nem tud törleszteni, így gyakorlatilag a központi bank kénytelen-kelletlen belemehet a törlesztés végtelen halaszthatóságába. Ezáltal ,a helikopterpénzt az úgynevezett örökjáradék kötvényhez teszi hasonlóvá, amelynél a fölvett tőkét akkor törleszthetjük, amikor akarjuk; addig csak a kamatokat kell fizetni rá. Az örökjáradék kötvény, ha lenne, megjelenne az állam

\footnotetext{
${ }^{23}$ Szegő Dániel (2020a): oldalszám nélkül. Kiemelések a szerzőtől!!
} 
adósságállományában, és rontaná (mint minden más adósság) az állam hitelképességét, növelve a tőle mint adóstól elvárt kamatokat." ${ }^{24}$

A kötvények lényege, hogy annak birtokosa vagy tulajdonosa a kötvény lejártakor visszakapja a névértéket, miközben a kibocsátó elöre rögzített módon kamatot fizet, és/vagy más szolgáltatást nyújt. Az örökjáradék kötvény (angolul perpetual bond) esetében nincs lejárat, azaz a kibocsátó mindig köteles kamatot fizetni, ugyanakkor a tökét (gyakorlatilag a hitelt) nem kell visszafizetnie. Azonban a kibocsátónak kellőképp hosszú idő után lehetősége van a kötvényt visszavásárolnia, ha akarja, de ekkor a tőkét vissza kell fizetnie.

A kötvény vásárlója tehát állandóan kap kamatot. Viszont ez az összeg, vagyis a tartozás az idők folyamán „elinflálódik”, tehát reál értékben egyre kevesebbet ér.

Egy ilyen kötvény esetén a kibocsátó azonnal hozzájut az összeghez, ami jelentős vonzerő. Az EU esetében - összehasonlítva egy véges idejü kötvénykibocsátással - ez kiegészül azzal az előnnyel, hogy a kormányok mentesülnének attól, hogy meghatározott időnként (3, 5 vagy 10 évenként) belemenjenek a lejáró kötvényállomány refinanszírozási módjával kapcsolatos politikai vitába.

Az örökjáradék kötvényt már régóta alkalmazzák. Például az Egyesült Királyságban a napóleoni háborúk vagy épp az első világháború kiadásainak finanszírozására, aztán 2012-ben is. Egy holland vízügyi hatóság a XVII. század közepén bocsátott ki mólóépítésre ilyen kötvényt, amelynek a kamatát még ma is kapja a Yale Egyetem. (Sztojcsev, 2020) Egyes országokban forgalomban vannak 40 és 50 éves futamidejü kötvények, de létezik 100 éves osztrák örökjáradék kötvény is. Magyarországon az OTP 2006-ban euróban bocsátotta ki az OPUS lejárat nélküli kötvényét, amelyet 2016. október végétől visszahívhatott volna, de nem tette meg.

Az Európai Bizottság még áprilisban úgy számolt, hogy kb. ezer milliárd euró kellene a koronavírus-járvány okozta gazdasági válság kezelésére, leginkább Olaszország és Spanyolországot támogatására. Megoldásként valójában négy lehetőség jöhetett szóba:

1. Tagállamok befizetéseit kellene növelni, és egy központi alapba befolyt pénzt lehetne szétosztani a rászorultság alapján. Kézenfekvő megoldásnak tünik, de a gond az, hogy

\footnotetext{
${ }^{24}$ Soós Károly Attila (2020): oldalszám nélkül. Kiemelés a szerzőtöl!
} 
a tagállamok a saját helyzetük finanszírozásával vannak elfoglalva, nagyobb befizetéseket nehezen tudnának teljesíteni.

2. Örökjáradék kötvény kibocsátásával, amit Soros György ötlete alapján Spanyolország vetett fel az Európai Tanács április végi ülésén. (Cué-De Miguel, 2020) Amennyiben 1000 milliárd eurót évi 0,5\% kamat mellett (ami nem elképzelhetetlen ${ }^{25}$ ) örökjáradék kötvény formájában bocsátana ki az EU, az évi 5 milliárd euró kiadás lenne az EU-nak. Az majd a kötvénykibocsátás során alakul ki, hogy melyik tagállam mennyi pénzt kapna, kinek mennyit kellene visszafizetnie, ahogy az is, hogy milyen feltételekkel vehetnének részt a programban a nem eurót használó országok.

3. Közös euróövezeti koronakötvény kibocsátásával, amit Franciaország és a déli államok vezetői vetettek fel. Lényege: fel kellene állítani egy pénzügyi alapot vagy átcsoportosítani az EU-s költségvetést úgy, hogy létrejöjjön egy kb. 500 milliárd eurós forrás, amely az eurótagállamok közös visszafizetési garanciájával bocsátana ki 8-10 éves kötvényeket, és az így befolyó pénzt nem az egyes országok nagysága, hanem szükségletei alapján osztanák szét. Mivel a kötvények csak 2027 után járnak le, így addig a költségvetéseket nem terheli kiadás. Azonban a magukat „takarékosok”-nak nevező országok (Ausztria, Svédország, Dánia és Hollandia) ${ }^{26}$ erőteljesen ellenezték ezt a javaslatot.

4. Marshall-segélyhez ${ }^{27}$ hasonló megoldással a beruházások erőteljes támogatása érdekében, amit Ursula von der Leyen, az Európai Bizottság elnöke vetett fel. Ez persze Németországra nagy terhet róna, de egyrészt Németország az európai egységfolyamat legnagyobb haszonélvezője, és másrészt a német állami fejlesztési bank forrásai között még mindig van olyan tétel - egy 12 milliárd eurós pénzalap -, amely a Marshall-terv programjaiból származik. Legfőképpen Olaszországot és a Spanyolországot kellene támogatni a segélyből.

Végül is az a javaslat született, hogy 750 milliárd eurónyi támogatási (koronavírusos helyreállítási) alapot (Next Generation EU) hoznának létre, amelyből 250 milliárd eurónyi rész az országok hozzájárulásának megemeléséből állna (a GNI 1,4\% körüli mértékének 2\%-ra

\footnotetext{
25 „Jelenleg a kormányzati euró kötvények lejárattól függő hozamai nulla körül ingadoznak, egyes országok esetében még a leghosszabb futamidő esetén is.” (Werner, 2020, oldalszám nélkül)

${ }^{26}$ Általában a „négy fukar” néven illetik ezen országokat, habár sok tekintetben Finnország is ide sorolható lenne.

${ }^{27}$ A háború utáni Marshall-tervben 17 európai ország 1952-ig összesen 14 milliárd dollárnyi segélyt kapott elsősorban amerikai áru formájában. Nagy-Britanniának jutott a segély 25\%-a, Franciaországnak 20\%-a, Olaszországnak 12\%-a, NSZK-nak pedig 10\%-a. Közismert, hogy Magyarország politikai okok miatt - a szovjetek elutasították az imperialista támogatást - nem részesülhetett a segélyből.
} 
történő megemelése által), míg a további 500 milliárd eurónyi értékben 3 és 30 év közötti időszakra szóló kötvénykibocsátásokból fedeznék. A 250 milliárd eurónyi visszatérítendő részt az érintett tagállamoknak valamikor 2028 és 2058 között kellene majd visszafizetniük a kötvények lejáratától függően. Az 500 milliárd eurónyi összeg vissza nem térítendő támogatásként kerülne az országokhoz. (A közös, 2020; Helyreállítási, 2020; Taktikát, 2020; Óriási, 2020; Darvas, 2020)

Az elfogadott javaslat szerint maradt 750 milliárd eurós a helyreállítási alap keretösszege, és 1074 milliárd euró a 2021-2027-es évekre szóló keretköltségvetés, valamint az eredeti 500-ról 390 milliárd euróra csökkent a vissza nem térítendő támogatási rész, és 250-ről 360 milliárd euróra emelkedett a hitel nagysága. (EU-csúcs, 2020)

\section{TANULSÁGOK}

A koronavírus-járvány számos problémát, negatív folyamatot, nehézséget okozott és valószínűleg okoz még mind a társadalmak, mind a gazdaságok számára. Ugyanakkor lehetőséget is adott eddig nem, vagy nem igazán alkalmazott eszközök, módszerek kipróbálására, használatára, és ezekből a tanulságok levonására. Ez nagyon sok területen igaz, így az oktatásban is.

A járvány alatt, az online oktatás során nemcsak azt tapasztaltuk meg, hogy máshogy is lehet/kell tanítani, hanem, hogy mást is kell oktatni. Át kell gondolni a közgazdaságtan eddigi oktatását, annak szerkezetét és tartalmát. Mindenképpen beszélni kell olyan gyakorlati módszerekről, amelyek eddig nem léteztek, vagy csak marginálisan voltak jelen. (Lásd például a cikkben részletesebben tárgyalt témákat: helikopter-pénz, Feltétel Nélküli Alapjövedelem, kurzarbeit, digitális jegybankpénz, örökjáradék kötvény; vagy a csak említés szintjén lévőket, például a negatív jövedelemadó, illetve a társadalmi örökség koncepció kérdéseit, valamint a különböző (szociális) támogatási megoldásokat). Mindenképpen helyre kell tenni, olyan kérdéseket, amelyek a hagyományos oktatási struktúrában nem szerepelnek, de az élet erőteljesen előtérbe helyezte azokat. (Lásd például az alternatív valuták, a kriptovaluták, a virtuális valuták és a digitális valuták fogalmának, használatának kérdéseit.) Mindenképpen meg kell mutatni, hogy a hagyományos közgazdaságtani iskolák mellett milyen új, alternatív megközelítések léteznek. (Lásd például amelyekről a tanulmány csak említett: QE for People mozgalom, Modern Monetáris Elmélet, Nemnövekedés mozgalom.) 


\section{JAVASLATOK}

Komárom-Esztergom megye egyetlen felsőoktatási intézményeként müködő, innovatív és vállalkozói személetű Edutus Egyetem feladata a térség számára a jól képzett, multidiszciplináris szemléletü, minőségi és motivált munkaerő utánpótlás biztosítása és helyben tartása a gazdasági és a müszaki területeken egyaránt. A képzési kínálat szélesítése és vonzóbbá tételének egyik részét jelentheti, ha a COVID-19 utáni gazdaságélénkítés újszerü monetáris és fiskális lehetőségeinek ismeretanyaga beépítésre kerül felsőoktatási gazdasági képzésekbe.

Az Edutus Egyetem alapszakos gazdasági képzései esetében a megoldást két irányban tartom elképzelhetőnek.

a) Az első lehetőség a Mikro- és Makroökonómia szemináriumi rendszerén való változtatás, és a példamegoldások egyszerüsítésével, némileg háttérbeszorításával kellene időt „nyerni” ezen témák közös feldolgozására.

b) A második lehetőség - vissza kellene hozni az I. félévre a Közgazdaságtani alapok tárgyat. Így az abban tisztázott alapfogalmak már nem kerülnének elő a Mikro- és Makroökonómia tantárgy keretében, tehát azoknál jutna elegendő idő az alternatív elméleti iskolák megközelítésére, új megoldások, lehetőségek bemutatására.

Egy dologban biztos vagyok: valamelyik út választása elkerülhetetlen az oktatás számára, annak érdekében, hogy a hallgatók naprakész, versenyképes tudást szerezzenek!

A gazdasági képzések tartalmi megújítása mellett a tantervi reformok és a szóban forgó szakmai tárgyak tematikáinak aktualizása mellett szükséges végiggondolni egyrészt a digitális, online oktatásban rejlő lehetőség jobb kihasználását, valamint új oktatási módszertani eszközök bevezetését a hatékony tudástranszfer megvalósítása érdekében.

\section{6. ÖSSZEFOGLALÁS}

A COVID-19 járvány okozta gazdasági recesszió jelentős kockázatait látva az egyes országok kormányai korábban példa nélküli fiskális intézkedéseket hoztak a gazdasági szereplők és háztartások megmentésére. A piacok leolvadásának megelőzésére a nemzeti jegybankok sorban jelentették be a hatalmas összegü monetáris expanziót, és ígéretet tettek a fiskális erőfeszítések finanszírozására is. Egyelőre még nem tudni, hogy a gazdasági recesszióból való kilábalás $U$, V, W, vagy L alakú lesz-e, de az optimális monetáris és fiskális eszköztár megtalálására a döntéshozók mindenhol jelentős erőfeszítéseket tesznek. 
Jelen cikk áttekinti a járvány utáni hazai gazdaságélénkítés néhány monetáris és fiskális eszközét, ismertetve az ezekkel kapcsolatos pro és kontra érveket, és mindezek mellett javaslatokat fogalmaz meg ezen ismeretanyagnak a felsőoktatási gazdasági képzésekbe való beépítési lehetőségeivel kapcsolatban. 


\section{Felhasznált szakirodalom}

1. 2020-ban (2019): 2020-ban jön a francia állami kriptovaluta, cryptofalka.hu, 12.09., https://cryptofalka.hu/hirek/2020-francia-allami-kriptovaluta/, letöltve: 2020-07-15

2. Az alapjövedelem (2020): Az alapjövedelem társadalmi megítélése, Republikon Intézet elemzése, Kézirat, 4 old., http://republikon.hu/media/38208/republikon_a\%CC\%81prilis_ alapjo\%CC\%88vedelem.pdf, letöltve: 2020-07-05

3. A finn (2020): A finn alapjövedelem-kísérlet tanulságai. jogaszvilag.hu, 05.08., https://jogaszvilag.hu/a-finn-alapjovedelem-kiserlet-tanulsagai/, letöltve: 2020-05-08

4. A többség (2014): A többség nem ért egyet a mindenkinek járó alapjövedelem ötletével, Századvég, 01.17., https://szazadveg.hu/hu/kutatasok/az-alapitvany-kutatasai/piackutataskozvelemeny-kutatas/a-tobbseg-nem-ert-egyet-a-mindenkinek-jaro-alapjovedelemotletevel, letöltve: 2020-07-05

5. akiraly (2020): Az európaiak jelentős többsége garantált alapjövedelemre vágyik. 444.hu, 05.07., $\quad$ https://444.hu/2020/05/07/az-europaiak-jelentos-tobbsege-garantaltalapjovedelemre-vagyik, letöltve: 2020-06-19

6. András Bence (2013): Miért nem nyomtatunk pénz és adjuk oda az embereknek? portfolio.hu, 08.16., http://www.portfolio.hu/gazdasag/miert_nem_nyomtatunk_penzt_es_adjuk_oda_az _embereknek.187993.html, letöltve: 2020-06-08

7. Ash, T.G. - Zimmermann, A. (2020): In Crisis, Europeans Support Radical Positions. Climate Change and Social Welfare issues most salient, eupinions brief, 6 Mai, https://eupinions.eu/de/text/in-crisis-europeans-support-radical-positions, letöltve: 2020-0619

8. Ádám Örs (2018): Feltétel Nélküli Alapjövedelem - Elmélet és Tények. Szakdolgozat, Budapesti Metropolitan Egyetem, 88 old.

9. Balás Gábor - Csite András (2020): Nem a magyar csomag mérete, hanem a tartalma és az időzítése a fontos! portfolio.hu, 04.02., https://www.portfolio.hu/gazdasag/20200402/ nema-magyar-csomag-merete-hanem-a-tartalma-es-az-idozitese-a-fontos-423762, letöltés: 202004-17

10. Bánfalvi István (2014): Vitaképtelenek. Élet és Irodalom, LVIII. évfolyam, 16. szám, 04.18., http://www.es.hu/banfalvi_istvan;vitakeptelenek;2014-04-17.html, letöltve: 2015-02-21

11. Bergmann, Barbara R. (2010): Svéd típusú jóléti állam, vagy alapjövedelem - melyik élvezzen prioritást? Esély 5. szám, 68-80. old.

12. Berlinger Edina (2020): Először a családokat mentsék, ne a vállalatokat! portfolio.hu, 04.01., https://www.portfolio.hu/gazdasag/20200401/eloszor-a-csaladokat-mentsek-ne-avallalatokat-423480, letöltve: 2020-04-17

13. Bihari Péter (2020a): Helikopterpénz kell Magyarországra a koronavírus ellen. portfolio.hu, 03.30., https://www.portfolio.hu/gazdasag/20200330/helikopterpenz-kell-magyarorszagraa-koronavirus-ellen-422750, letöltve: 2020-03-30

14. Bihari Péter (2020b): Koronavírusra helikopterpénzt: okoz-e adósságnövekedést a bankóprés? portfolio.hu, 04.14., https://www.portfolio.hu/gazdasag/20200414/koronavirusra-helikopterpenzt-okoz-eadossagnovekedest-a-bankopres-425760, letöltve: 2020-04-17

15. Bogár László (2020): Pénzkommunizmus, Magyar Hírlap, 06.15., https://www.magyarhirlap.hu/velemeny/20200615-penzkommunizmus, letöltve: 2020-07-09 
16. Bokros Lajos (2020a): Reccsen a koponya. Élet és Irodalom, LXIV. évfolyam, 13. szám, 03.27., https://www.es.hu/cikk/2020-03-27/bokros-lajos/reccsen-a-koponya.html, letöltve: 2020-06-16

17. Bokros Lajos (2020b): Milyen módon támogassuk a járvány okozta válság gazdasági kárvallottjait? Városi Kurír, 03.31., https://varosikurir.hu/vita-a-letpenzrol-4-bokros-lajosmilyen-modon-tamogassuk-a-jarvany-okozta-valsag-gazdasagi-karvallottjait/, letöltve: 2020-03-31

18. Borowski, Didier (2020): Járatlan utakon a fiskális és a monetáris politika a járvány óta, index.hu, https://index.hu/gazdasag/penzbeszel/2020/07/13/jaratlan_utakon_a_fiskalis _es_a_monetaris_politika_a_jarvany_ota/, letöltve: 2020-07-15

19. Brückner Gergely (2020a): A koronavírus megszabadíthat minket a készpénztől, index.hu, 04.19., https://index.hu/gazdasag/2020/04/19/a_koronavirus_megszabadithat_minket_a_ keszpenztol_hoditanak_a_kontaktmentes_fizetesek/, letöltve: 2020-07-09

20. Brückner Gergely (2020b): Jó ötlet Sorostól az 1000 milliárd eurós pénzosztás?, index.hu, 05.12., https://index.hu/gazdasag/2020/05/12/azt_tanultuk_hogy_nem_lehet_csak_ugy_ nyomtatni_a_penzt._vagy_megis/, letöltve: 2020-07-15

21. Chohan, Usman W. (6 April 2020). "Modern Monetary Theory (MMT): A General Introduction". CASS Working Papers on Economics \& National Affairs. Social Science Research Network. EC017UC (2020). Retrieved 27 July 2020.

22. Coronado, J. - Potter, Simon M. (2020a): Securing Macroeconomic and Monetary Stability with a Federal Reserve - Backed Digital Currency. Peterson Institute for International Economics, Policy Brief, March, Issue 4., pp. 11, https://www.piie.com/system/files/documents/pb20-4.pdf, letöltve: 2020-07-20

23. Coronado, J. - Potter, Simon M. (2020b): Reviving the Potency of Monetary Policy with Recession Insurance Bonds. Peterson Institute for International Economics, Policy Brief, April, Issue 5., pp. 16, https://www.piie.com/system/files/documents/pb20-5.pdf, letöltve: 2020-07-20

24. Cué, Carlos E. - De Miguel, Bernardo (2020): Spain proposes a $€ 1.5$ trillion coronavirus recovery fund financed through perpetual EU debt, Madrid / Brussels, El País, https://english.elpais.com/politics/2020-04-20/spain-proposes-a-15-trillion-coronavirusrecovery-fund-financed-through-perpetual-eu-debt.html, letöltve: 2020-07-15

25. CsD (2020): Már 9500 cég kapott bértámogatást a kormánytól, index.hu, 05.26., https://index.hu/gazdasag/allas/2020/05/26/palkovics_laszlo_bertamogatas_kurzarbeit/, letöltve: 2020-06-01

26. Csillag István - Mihályi Péter (2014a): Tizenkét érv a feltétel nélküli alapjövedelemmel szemben. Élet és Irodalom, LVIII. évfolyam, 3. szám, 01.17., https://www.es.hu/cikk/201401-17/csillag-istvan-mihalyi-peter/tizenket-erv-a-feltetel-nelkuli-alapjovedelemmelszemben-.html, letöltve: 2020-06-11

27. Csillag István - Mihályi Péter (2014b): Huszonegy közgazdasági érv a feltétel nélküli alapjövedelemmel szemben. Competitio, Debreceni Egyetem, 13. évf. 1. szám, 5-29. old., https://doi.org/10.21845/comp/2014/1/1, letöltve: 2020-06-11

28. Csillag István-Mihályi Péter (2014c): Mi a szegényekkel vagyunk. (Vitazáró a feltétel nélküli alapjövedelemröl.), Élet és Irodalom, LVIII. évfolyam, 14. szám, 04.04., http://www.es.hu/csillag_istvan8211;mihalyi_peter;mi_a_szegenyekkel_vagyunk;2014-0403. html, letöltve: 2015-02-21 
29. Darvas Zsolt (2020): Eső után köpönyeg lehet az EU koronavírus-mentőalapja, portfolio.hu, 06.15., $\quad$ https://www.portfolio.hu/krtk/20200615/eso-utan-koponyeg-lehet-az-eukoronavirus-mentoalapja-436744, letöltve: 2020-07-08

30. Dedák István (2020): Pénzt szórni a nép közé, avagy mikor repül ingyen a helikopter? portfolio.hu, 05.29., https://www.portfolio.hu/gazdasag/20200529/penzt-szorni-a-nep-kozeavagy-mikor-repul-ingyen-a-helikopter-433720, letöltve: 2020-05-29

31. Domokos László (2020): Alapjövedelem: zavarba ejtő eredmény született. napi.hu, 06.09., https://www.napi.hu/magyar_gazdasag/pulzus-alapjovedelem-jovedelem-tamogataskozvelemeny-kutatasmunka.707715.html?utm_source=index.hu\&utm_medium=doboz\&utm _campaign=link, letöltve: 2020-06-09

32. Elgarte, Julieta (2010): Az alapjövedelem és a nemi szerepek szerinti munkamegosztás összefüggései, Esély 5. szám, 61-67. old.

33. Előd Fruzsina (2020): Élesben próbálja ki a világ, mi van, ha az állam csak úgy pénzt ad az embereknek, index.hu, 04.08., https://index.hu/gazdasag/2020/04/08/koronavirus_valsag_ munkanelkuliseg_segely_helyett_alapjovedelem_fna_minimumjovedelem/, letöltve: 202006-08

34. Essősy Zsombor (2020): Szolidaritás és versenyképesség - avagy újratervezés a reálgazdaságban. portfolio.hu, 04.02., https://www.portfolio.hu/gazdasag/20200402/ szolidaritas-es-versenykepesseg-avagy-ujratervezes-a-realgazdasagban-423630, letöltve: 2020-04-17

35. EU-csúcs (2020): EU-csúcs: megvan a megállapodás!, portfolio.hu, 07.21., https://www.portfolio.hu/unios-forrasok/20200721/eu-csucs-megvan-a-megallapodas441638, 2020-07-21

36. F. Liska Tibor (1998): A Liska-modell, Közgazdasági Szemle, XLV. évfolyam, 10. szám, 940-953. old.

37. F. Liska Tibor (2014): Alapjövedelem és „társadalmi-örökség”. Élet és Irodalom, LVIII. évfolyam, $7 . \quad$ szám, 02.14., http://www.es.hu/f_liska_tibor;alapjovedelem_es_8222;tarsadalmi-orokseg8221;;2014-0213.html, letöltve: 2015-02-21

38. Felcsuti Péter - Molnár György (2014): A kritika kritikája. Hozzászólás a feltétel nélküli alapjövedelemről szóló vitához., Élet és Irodalom, LVIII. évfolyam, 5. szám, 01.31., http://www.es.hu/felcsuti_peter8211;molnar_gyorgy;a_kritika_kritikaja;2014-01-29.html, letöltve: 2015-02-21

39. Ferge Zsuzsa (2014): A lét jogán. dinamo.blog.hu, 01.17., https://dinamo.blog.hu/2014/01/17/a_let_jogan\#more5761550, letöltve: 2020-06-13

40. Friedman, Milton (1967): "The Case for the Negative Income Tax", National Review, 7 March, pp. 239-241

41. Friedman, Milton (1969): The Optimun Quantity of Money, London, Macmillan, pp. 296

42. Györfi András (2020): Digitális dollárt hozhat a válságkezelés, 03.27., https://hu.coincash.eu/blog/digitalis-dollart-hozhat-a-valsagkezeles, letöltve: 2020-07-09

43. Gyükeri Mercédesz (2020) Csúsztat a kormány, amikor azt állítja: adósrabszolgává teszi az EU a magyarokat, hvg.hu, 07.09., https://hvg.hu/gazdasag/20200709_Csusztat_a_kormany_ mikor_arrol_beszel_adosrabszolgava_teszi_az_EU_a_magyarokat, letöltve: 2020-07-15 
44. Hardi Zsuzsanna és Szapáry György (2020): Gazdasági intézkedések a koronavírus ellen: nemzetközi összehasonlítás, portfolio.hu, 06.18., https://www.portfolio.hu/gazdasag/ 20200618/gazdasagi-intezkedesek-a-koronavirus-ellen-nemzetkozi-osszehasonlitas-437398, letöltve: 2020-06-19

45. Helyreállítási (2020): Helyreállítási alap = A következő generációs EU, portfolio.hu, 05.07., https://www.portfolio.hu/unios-forrasok/20200527/itt-a-nagy-eu-s-helyreallitasi-tervreszletei -750-milliardos-alap-jon-434154, letöltve: 2020-05-29

46. Hugh Frazer, H. - Marlier, E. (2010): Minimumjövedelmi rendszerek az EU tagállamaiban, Esély 5. szám, 81-139. old.

47. Helikopter pénz (2017): Helikopter pénz: Mit jelent? Milyen hatása lesz a gazdaságra? Elemzésközpont, 11.01., https://elemzeskozpont.hu/helikopter-penz-mit-jelent-milyenhatasa-lesz-gazdasagra, letöltve: 2020-05-24

48. Horváth Irén (2014): Feltétel Nélküli Alapjövedelem. Országgyülés Hivatala, infojegyzet, 52. szám, 06.07., 4 old.

49. Huszák Dániel (2020) A koronavírus viheti be a készpénznek a kegyelemdöfést? portfolio.hu, 04.24., $\quad$ https://www.portfolio.hu/gazdasag/20200424/a-koronavirus-viheti-be-akeszpenznek-a-kegyelemdofest-427708, letöltve: 2020-04-24

50. Ingyen (2018): Ingyen pénz: alanyi jogon 10000 fontot adnának minden britnek, qubit.hu, 02.16., https://qubit.hu/2018/02/16/ingyen-penz-alanyi-jogon-10-000-fontot-adnanakminden-britnek, letöltve: 2020-07-04

51. Illés Gergő (2020): Soros: Mire az EU-tagok felismerik, hogy az örökjáradék-kötvények elkerülhetetlenek, már túl késő lesz, azonnali.hu, 06.29., https://azonnali.hu/cikk/ 20200629_soros-mire-az-eu-tagok-felismerik-hogy-az-orokjaradek-kotvenyek-

elkerulhetetlenek-mar-tul-keso-lesz, letöltve: 2020-07-07

52. Iványi György (2014): Jóléti rendszerváltás vagy politikai csapda? Az állampolgári alapfizetés víziójáról. Élet és Irodalom, LVIII. évfolyam, 5. szám, 01.31., http://www.es.hu/ivanyi_gyorgy;joleti_rendszervaltas_vagy_politikai_csapda;2014-01-29. html, letöltve: 2015-02-21

53. JM (2013): Járjon pénz csak azért, mert élünk? index.hu, 05.31.,https://index.hu/gazdasag/2013/05/31/alapjovedelem/, letöltve: 2020-06-08

54. Jöhet (2020): Jöhet az 1200 dolláros csekk a munkanélküli amerikaiaknak, meghosszabbíthatják a moratóriumot is. portfolio.hu, 07.26., https://www.portfolio.hu/gazdasag/20200726/johet-az-1200-dollaros-csekk-amunkanelkuli-amerikaiaknak-meghosszabbithatjak-a-moratoriumot-is-442538, letöltve: 2020-07-27

55. Kertész Krisztián (2020): Koronavírus-válság: Óvatosan a fiskális élénkítéssel!, portfolio.hu, 04.18., https://www.portfolio.hu/gazdasag/20200418/koronavirus-valsag-ovatosan-afiskalis-elenkitessel-425998, letöltve: 2020-04-20

56. Kicsid Attila (2016): Használhatná az EKB a pénzhelikoptert, és pénzt oszthatna szét az emberek között? penzcsinalok.transindex.ro. 03.21., https://penzcsinalok.transindex.ro/ penzpiac/20160318-hasznalhatna-az-ekb-a-penzhelikoptert-es-penzt-oszthatna-szet-azemberek-kozott, letöltve: 2020-05-29

57. Kis Miklós (2020): Havi százezer forint alapjövedelmet most! - Ne kelljen választani tanulás és megélhetés között! Városi Kurír, 04.01., https://varosikurir.hu/kis-mikos-havi-szazezer- 
forint-alapjovedelmet-most-ne-kelljen-valasztani-tanulas-es-megelhetes-kozott/, letöltve: 2020-04-01

58. Komócsin Sándor (2020): Újra bevetik a német csodafegyvert, napi.hu, 03.28., https://www.napi.hu/nemzetkozi_gazdasag/koronavirus-jarvany-valsag-munka-allas-nemetmunkaido.702774.html, letöltve: 2020-07-07

59. A Kormány (2020a): A Kormány 105/2020. (IV. 10.) Korm. rendelete a veszélyhelyzet idején történő csökkentett munkaidős foglalkoztatásnak a Gazdaságvédelmi Akcióterv keretében történő támogatásáról, Magyar Közlöny, 71. szám, 1943-1946. old.

60. A Kormány (2020b): A Kormány 141/2020. (IV. 21.) Korm. rendelete a kutató-fejlesztő tevékenységet végző munkavállalók veszélyhelyzet idején megvalósuló foglalkoztatásának a Gazdaságvédelmi Akcióterv keretében történő támogatásáról szóló 103/2020. (IV. 10.) Korm. rendelet, valamint a veszélyhelyzet idején történő csökkentett munkaidős foglalkoztatásnak a Gazdaságvédelmi Akcióterv keretében történő támogatásáról szóló 105/2020. (IV. 10.) Korm. rendelet módosításáról, Magyar Közlöny, 82. szám, 2141-2144. old.

61. Koronavírus (2020): Koronavírus: egyszeri pénzjuttatást kapnak az izraeli állampolgárok, portfolio.hu, 07.16., https://www.portfolio.hu/gazdasag/20200716/koronavirus-egyszeripenzjuttatast-kapnak-az-izraeli-allampolgarok-441398, letöltve: 2020-07-16

62. Kovács Krisztián (2020): Monetáris kommunizmus, avagy pénzt a rászorulóknak!, index.hu, 06.06., https://index.hu/gazdasag/penzbeszel/2020/06/06/monetaris_kommunizmus_avagy_ penzt_a_raszoruloknak/, letöltve: 2020-06-07

63. A közös (2020): A közös kötvénykibocsátás fö keretei, portfolio.hu, 05.27., https://www.portfolio.hu/unios-forrasok/20200527/itt-a-nagy-eu-s-helyreallitasi-tervreszletei -750-milliardos-alap-jon-434154, letöltve: 2020-05-29

64. Lehmann Kristóf - Vonnák Balázs (2020): Ingyenpénzt a nép közé? A helikopter sem repül ingyen. portfolio.hu, 04.05., https://www.portfolio.hu/gazdasag/20200405/ingyenpenzt-anep-koze-a-helikopter-sem-repul-ingyen-423980, letöltve: 2020-04-17

65. Lendvai Ildikó (2020): A szociális válság ellen - nyakunkon egy szociális krízis. Városi Kurír, 03.31., https://varosikurir.hu/vita-a-letpenzrol-3-a-szocialis-valsag-ellen-nyakunkonegy-szocialis-krizis/, letöltve: 2020-03-31

66. LÉT (2014): A LÉT, ajánlat a magyar társadalomnak. 25-50-75. Tanulmány, LÉT Szakértői Csoport, 98 old., http://let.azurewebsites.net/upload/tanulmany.pdf, letöltve: 2014-06-15

67. Liegey, V. - Madelaine, S. - Ondet, C. - Veillot, A-I. (2013): Jólét gazdasági növekedés nélkül. A Nemnövekedés felé. Kiáltvány a Feltétel Nélküli Alapjuttatásért (FNA), Eszmélet, 100. szám, tél, Melléklet, 100 old.

68. Liskáné Pólya Lenke (2020): A mindenkinek járó alapjövedelem?! - Mikor és hogyan? Városi Kurír, 04.14., https://varosikurir.hu/vita-a-letpenzrol-7-liskane-polya-lenke-amindenkinek-jaro-alapjovedelem-mikor-es-hogyan/, letöltve: 2020-05-20

69. Ludassy Mária (2014): 12 érv plusz 1, Élet és Irodalom, LVIII. évfolyam, 4. szám, 01.24., http://www.es.hu/ludassy_maria;12_erv_plusz_1;2014-01-23.html, letöltve: 2015-02-21

70. Ma jöhet (2020): Ma jöhet a nagy bejelentés: újra helikopterpénzt kaphat az amerikai lakosság, portfolio.hu, 07.23., https://www.portfolio.hu/befektetes/20200723/ma-johet-anagy-bejelentes-ujra-helikopterpenzt-kaphat-az-amerikai-lakossag-442168, letöltve: 202007-27 
71. Madár István (2020): Koronavírus-válság: sürgősen ki kell találni valami újat, különben összeomlik a gazdaság. portfolio.hu, 04.14., https://www.portfolio.hu/gazdasag/ 20200414/koronavirus-valsag-surgosen-ki-kell-talalni-valami-ujat-kulonben-osszeomlik-agazdasag-425582, letöltve: 2020-05-18

72. Marton Ádám (2020): Fókuszban a munkaerőpiac és a Kurzarbeit válságkezelési intézkedései - német és osztrák recept, ludovika.hu, 06.08., https://www.ludovika.hu/blogok /ludeconblog/2020/06/08/fokuszban-a-munkaeropiac-es-a-kurzarbeit-valsagkezelesiintezkedesei-nemet-es-osztrak-recept/, letöltve: 2020-07-07

73. Matolcsy György (2020): A pénzforradalom évei jönnek, novekedes.hu, 05.04., https://novekedes.hu/mag/a-penzforradalom-evei-jonnek, letöltve: 2020-07-10

74. Már (2020): Már kétszázezer embernek kértek munkahelyvédelmi bértámogatást, portfolio.hu, 07.17., https://www.portfolio.hu/gazdasag/20200717/mar-ketszazezerembernek-kertek-munkahelyvedelmi-bertamogatast-441584, letöltve: 2020-07-17

75. Márton Szilárd (2018): Alanyi jogon járó fizetés: jöhet az ingyen pénz korszaka? index.hu, 11.08., https://index.hu/gazdasag/penzbeszel/2018/11/08/alanyi_jogon_jaro_fizetes_johet_az_ ingyen_penz_korszaka/, letöltve: 2020-06-08

76. Mészáros R. Tamás (2020): Jön a kínai antibitcoin, index.hu, 04.30., https://index.hu/gazdasag/2020/04/30/kina_juan_digitalis_penz_valuta_kriptovaluta_bitcoin _anti-bitcoin/, letöltve: 2020-07-09

77. Misetics Bálint (2010): Egy radikális társadalompolitikai reformgondolat. Előszó az Alapjövedelem - minimumjövedelem tematikus számhoz, Esély 5. szám, 3-8. old.

78. Mückenberger, U. - Offe, C. - Ostner, I. (2010): Az állam által garantált alapjövedelem: napjaink szociálpolitikai szükségszerüsége, Esély 5. szám, 42-60. old.

79. Németh György (2020): A tisztánlátás igényével - A helikopterpénzröl. portfolio.hu, 06.13., https://www.portfolio.hu/gazdasag/20200613/a-tisztanlatas-igenyevel-a-helikopterpenzrol436310, letöltve: 2020-06-13

80. Orban (2020): Orban: Megpróbáljuk gyakorlatba ültetni a Kurzarbeit-modellt, erdon.ro, 06.22., https://www.erdon.ro/romania/orban-megprobaljuk-gyakorlatba-ultetni-a-kurzarbeitmodellt-2934356/, letöltve: 2020-07-07

81. Óriási (2020): Óriási viták várhatók az uniós pénzek körül - Magyarország járhat a legrosszabbul, portfolio.hu, 06.16., https://www.portfolio.hu/gazdasag/20200616/oriasivitak-varhatok-az-unios-penzek-korul-magyarorszag-jarhat-a-legrosszabbul-437150, letöltve: 2020-07-08

82. Palotai Dániel - Virág Barnabás (2020a): A koronavírus-járvány gazdasági következményeinek kezelése - egy másik lehetséges megoldás. portfolio.hu, 03.30., https://www.portfolio.hu/ gazdasag/20200330/a-koronavirus-jarvany-gazdasagikovetkezmenyeinek-kezelese-egy-masik-lehetseges-megoldas-422882, letöltve: 2020-03-30

83. Palotai Dániel - Virág Barnabás (2020b): Koronavírus-járvány hatásai - célkeresztben a tények és „V”-alakú kilábalás. portfolio.hu, 04.07., https://www.portfolio.hu/gazdasag/ 20200407/koronavirus-jarvany-hatasai-celkeresztben-a-tenyek-es-v-alaku-kilabalas424608, letöltve: 2020-04-17

84. Pályi András (2014): Nem válasz., Élet és Irodalom, LVIII. évfolyam, 4. szám, 01.24., http://www.es.hu/palyi_andras;nem_valasz;2014-01-23.html, letöltve: 2015-02-21 
85. Van Parijs, Philippe (2010): Alapjövedelem: egy egyszerü és eröteljes gondolat a huszonegyedik század számára, Esély 5. szám, 9-41. old.

86. Petrus Szabolcs (2020): EU - Gigantikus mentőcsomagok hitelböl. Mi is az a Kurzarbeit? azuzlet.hu, 04.09., https://azuzlet.hu/eu-gigantikus-mentocsomagok-hitelbol-mi-is-az-akurzarbeit/, letöltve: 2020-07-07

87. Pogátsa Zoltán (2019): A feltétel nélküli alapjövedelem értelme és a finn kísérlet haszontalansága. eszak.org, 02.17., https://www.eszak.org/2019/02/17/pogatsa-zoltan-afeltetel-nelkuli-alapjovedelem-ertelme-es-a-finn-kiserlet-haszontalansaga/, letöltve: 202006-03

88. Prinz Dániel (2019): Miért nem jó ötlet a feltétel nélküli alapjövedelem? qubit.hu, 06.13., https://qubit.hu/2019/06/13/miert-nem-jo-otlet-a-feltetel-nelkuli-alapjovedelem, letöltve: 2020-07-04

89. QE FOR PEOPLE (évszám nélkül): QE FOR PEOPLE, positivmoney.org, dátum nélkül, https://positivemoney.org/what-we-do/qe-for-people/, letöltve: 2020-06-04

90. Radnai György (2014): Érvek? Élet és Irodalom, LVIII. évfolyam, 8. szám, 02.21., http://www.es.hu/dr_radnai_gyorgy;ervek1;2014-02-19.html, letöltve: 2015-02-21

91. Rácz Gergő (2020): Fordulat: változás a digitális pénzvilágban, napi.hu, 03.05., https://www.napi.hu/tech/bitcoin-szabalyozas-kriptodeviza-penz-elektronikusnemetorszag.701515.html, letöltve: 2020-07-09

92. Rádai Eszter (2014): Feltétel nélküli alapjövedelem. Bánfalvi István szociálpolitikai szakértővel Rádai Eszter készített interjút. Élet és Irodalom, 01.31., www.egyhazestarsadalom.hu/.../Rádai-Eszter-interjúja-Bánfalvi-Istvánnal..., letöltve: 2015$02-23$

93. Rátesi Margit (2014): Feltétel nélküli lét. Élet és Irodalom, LVIII. évfolyam, 16. szám, 04.18., http://www.es.hu/ratesi_margit;feltetel_nelkuli_let;2014-04-17.html, letöltve: 2015-02-21

94. Regős Gábor (2020): Mentsük a menthetőt a koronavírus-válságban! portfolio.hu, 04.17., https://www.portfolio.hu/gazdasag/20200417/mentsuk-a-menthetot-a-koronavirusvalsagban-426390, letöltve: 2020-05-18

95. Rengeteg (2020): Rengeteg ember életét tette tönkre a koronavírus, és az igazi veszély a második hullám, portfolio.hu, 07.12., https://www.portfolio.hu/gazdasag/20200712/rengeteg-ember-eletet-tette-tonkre-akoronavirus-es-az-igazi-veszely-a-masodik-hullam-440738, letöltve: 2020-07-12

96. Retkes Ádám István (2020): A digitális jegybankpénz vezetheti a bankrendszert a 21. századba, makronom.mandiner.hu,

06.30., https://makronom.mandiner.hu/cikk/20200630_a_digitalis_ jegybankpenz_vezetheti_a_bankrendszert_a_21_szazadba, letöltve: 2020-07-10

97. Róna Péter (2020) A kormány, a múlt nélküli jövő és a helikopterpénz. magyarhang.org, 04.07., https://magyarhang.org/publicisztika/2020/04/07/a-kormany-a-mult-nelkuli-jovo-esa-helikopterpenz/, letöltve: 2020-05-29

98. Samu János (2020): Bízzuk-e a vírusra a szerkezetátalakítást? index.hu, 04.14., https://index.hu/gazdasag/penzbeszel/2020/04/15/bizzuke_a_virusra_a_szerkezetatalakitast/, letöltve: 2020-04-15

99. Sárosi Péter (2020): Feltétel nélküli alapjövedelem: 8 legyet egy csapásra. cimlap.blog.hu, 04.05., 
https://cimlap.blog.hu/\#bloghu/pendulum/2020/04/05/feltetel_nelkuli_alapjovedelem _ _ _ legyet_egy_csapasra, letöltve: 2020-04-06

100. Sebestyén Szabolcs (2020): Pénzt szórni a nép közé - Mire jó a helikopterpénz? portfolio.hu, 06.11., https://www.portfolio.hu/gazdasag/20200611/penzt-szorni-a-nep-koze-mire-jo-ahelikopterpenz-435982, letöltve: 2020-06-11

101. Sheahen, A. (2015): Basic Income Guarantee: Your Right to Economic Security. Palgrave Macmillan US, pp. 204

102. Sipos Ildikó (2020): Alapvetően két irányzat közül választanak az országukat mentő vezetők. Riport Palócz Évával, a Kopint-Tárki vezérigazgatójával. Infostart/InfoRádió, 04.07., https://infostart.hu/gazdasag/2020/04/07/alapvetoen-ket-iranyzat-kozul-valasztanak-azorszagukat-mento-vezetok, letöltve: 2020-05-25

103. Soós Károly Attila (2014): Lehet-e róla komolyan vitázni? Élet és Irodalom, LVIII. évfolyam, 10. szám, 03.07., http://www.es.hu/soos_karoly_attila;lehet-e_rola_komolyan_vitazni;201403-06.html, letöltve: 2015-02-21

104. Soós Károly Attila (2020): A helikopterpénz ötletéről. portfolio.hu, 05.18., https://www.portfolio.hu/gazdasag/20200518/a-helikopterpenz-otleterol-432140, letöltve: 2020-05-18

105. Stanislas Jourdan (2019): Újra kell gondolniuk pénz és társadalom kapcsolatát. Green European Journal, 08.28., https://www.greeneuropeanjournal.eu/ujra-kell-gondolniuk-penzes-tarsadalom-kapcsolatat/, letöltve: 2020-05-24

106. Surány Gábor (2020). 80.000 forint havi létpénzt millióknak, most! Itt a jó alkalom! Városi Kurír, 03.29., https://varosikurir.hu/80-000-forint-havi-letpenzt-millioknak-most-itt-a-joalkalom/, letöltve: 2020-03-31

107. Surányi György (2020a): Surányi György a koronavírus-válságról: A kezelés egy lehetséges iránya. portfolio.hu, 03.25., https://www.portfolio.hu/gazdasag/20200325/suranyi-gyorgy-akoronavirus-valsagrol-a-kezeles-egy-lehetseges-iranya-421802, letöltve: 2020-03-30

108. Surányi György (2020b): Ki ült tehát fordítva a lovon? portfolio.hu, 04.02., https://www.portfolio.hu/gazdasag/20200402/suranyi-gyorgy-a-koronavirus-valsagrol-kiult-tehat-forditva-a-lovon-423654, letöltve: 2020-04-17

109. Stojcsev Iván (2020): Tényleg adósrabszolgaságot hozna Soros új csodafegyvere?, hvg.hu, 04.24., $\quad$ https://m.hvg.hu/gazdasag/20200424_orokjaradek_kotveny_soros_orban_eu_ koronavirus_valsag?utm_source $=$ mandiner\&utm_medium $=$ link $\& u t m \_c a m p a i g n=$ mandiner _202006, letöltve: 2020-06-19

110. Sz. A. (2020): Mennyire bőkezű a hazai bértámogatás a többi visegrádi országéhoz képest? novekedes.hu, 05.20., https://novekedes.hu/elemzesek/mennyire-bokezu-a-hazaibertamogatas-a-tobbi-visegradi-orszagehoz-kepest, letöltve: 2020-07-07

111. Szabó Zsuzsanna (2020): Alapjövedelem: nagy meglepetést okozott egy széleskörü felmérés. napi.hu, 05.07., https://www.napi.hu/nemzetkozi_gazdasag/klimavaltozas-alapjovedelemkozvelemeny-kutatas-fiatal-idos.705783.html, letöltve: 2020-06-19

112. Szabó Gergely - Kollarik András (2017): Az MNB elmagyarázza mi is az a digitális jegybankpénz, portfolio.hu, 11.05., https://www.portfolio.hu/uzlet/20171105/az-mnbelmagyarazza-mi-is-az-a-digitalis-jegybankpenz-266855, letöltve: 2019-09-23

113. Szalai Zoltán (2020): „Helikopterpénz” MMT nézőpontból. mnbtanszekblog.hu, 05.21., https://mnbtanszekblog.hu/2020/05/21/helikopterpenz-mmt-nezopontbol/ , letöltve: 2020-05-25 
114. Szanyi Tibor (2020): Pénzt kell juttatni az embereknek, de hogyan? Városi Kurír, 03.30., https://varosikurir.hu/penzt-kell-juttatni-az-embereknek-de-hogyan/, letöltve: 2020-03-31

115. Szegő Dániel (2020a): Küszöbön a digitális jegybankpénz. Íme a legfontosabb tudnivalók., fintechzone.hu, 06.08., https://fintechzone.hu/uton-a-digitalis-jegybankpenz-fele/, letöltve: 2020-07-10

116. Szegő Dániel (2020b): A digitális dollár projekt: ilyen lehet majd a digitális jegybankpénz, fintechzone.hu, 07.03., https://fintechzone.hu/a-digitalis-dollar-projekt-ilyen-lehet-majd-adigitalis-jegybankpenz/, letöltve: 2020-07-09

117. Szücs Ágnes (2020): Egy EU-s kutatás szerint a magyarok 35 százaléka vesztette el a munkáját részben vagy egészben a járvány miatt, index.hu, 07.14., https://index.hu/kulfold/eurologus/2020/07/14/magyar_europai_gazdasag_koronavirus_unio s_koltsegvetes_kutatas/, letöltve: 2020-07-15

118. Taktikát (2020): Taktikát váltott a négy fukar és ez jó jel Magyarországnak is: összejöhet a nagy EU-s alku, portfolio.hu, 05.31., https://www.portfolio.hu/uniosforrasok/20200531/taktikat-valtott-a-negy-fukar-es-ez-jo-jel-magyarorszagnak-isosszejohet-a-nagy-eu-s-alku-434766, letöltve: 2020-05-31

119. Tamás Tibor (2020a): Emlékszik még valaki Széchenyire? - Lengyel Lászlótól Bokros Lajosig. Városi Kurír, 03.30., https://varosikurir.hu/vita-a-letpenzrol-2-emlekszik-megvalaki-szechenyire-lengyel-laszlotol-bokros-lajosig/, letöltve: 2020-03-31

120. Tamás Tibor (2020b): Létpénz-vita: ne keverjük az alapjövedelmet a segéllyel! Városi Kurír, 04.03., https://varosikurir.hu/letpenz-vita-ne-keverjuk-az-alapjovedelmet-a-segellyel/, letöltve: 2020-04-03

121. Tóth I. János (2020): Az örök kötvény immoralitása, Barankovics Alapítvány, 05.14., https://barankovics.hu/cikk/idoszeru/az-orok-kotveny-immoralitasa, letöltve: 2020-06-19

122. Turzó Ádám Pál (2020): Készpénzben fuldoklik a magyar gazdaság, a legjobbkor jön a kormány drasztikus lépése, portfolio.hu, 06.05., https://www.portfolio.hu/uzlet/20200605/ keszpenzben-fuldoklik-a-magyar-gazdasag-a-legjobbkor-jon-a-kormany-drasztikus-lepese435488, letöltve: 2020-06-05

123. Veres János (2020): Átfogó, gyors, bátor lépések kellenek. portfolio.hu, 03.31., https://www.portfolio.hu/gazdasag/20200331/veres-janos-a-koronavirus-valsag-kezeleserolatfogo-gyors-bator-lepesek-kellenek-422982, letöltés: 2020-04-01

124. Véget (2020): Véget ér a román kurzarbeit, portfolio.hu, 05.29., https://www.portfolio.hu/gazdasag/20200529/veget-er-a-roman-kurzarbeit-434540, letöltve: 2020-07-07

125. Virtuális (2020): Virtuális devizát dobhat a piacra a legnagyobb japán bank, portfolio.hu, 07.15., $\quad$ https://www.portfolio.hu/bank/20200715/virtualis-devizat-dobhat-a-piacra-alegnagyobb-japan-bank-441256, letöltve: 2020-07-15

126. Weinhardt Attila (2020a): Tényleg történelmi lépésre készülnek Merkelék vírus ügyben Íme, a magyar kormánynak is fontos szálak, portfolio.hu, 05.19., https://www.portfolio.hu/unios-forrasok/20200519/tenyleg-tortenelmi-lepesre-keszulnekmerkelek-virus-ugyben-ime-a-magyar-kormanynak-is-fontos-szalak-432798, letöltve: 202005-19

127. Weinhardt Attila (2020b): Sok vagy kevés pénzt kap Magyarország az EU új alapjából? Ez az ábra egyértelmüen megmutatja, portfolio.hu, 06.26., https://www.portfolio.hu/unios- 
forrasok/20200626/sok-vagy-keves-penzt-kap-magyarorszag-az-eu-uj-alapjabol-ez-az-abraegyertelmuen-megmutatja-438860, letöltve: 2020-06-27

128. Werner, Riecke (2020): Az EU örökjáradék kötvénye - egy álprobléma és egy látszólagos megoldás, portfolio.hu, 05.04., https://www.portfolio.hu/gazdasag/20200504/az-euorokjaradek-kotvenye-egy-alproblema-es-egy-latszolagos-megoldas-429750, letöltve: 202005-04

129. Will, Henner (2010): Kurzarbeit als Flexibilisierungsinstrument Hemmnis strukturellen Wandels oder konjunkturelle Brücke für Beschäftigung? Institut für Makroökonomie und Konjukturforshung, Study, Düsseldorf, November, pp. 92, https://www.boeckler.de/pdf/p_imk_study_5_2010.pdf, letöltve: 2020-08-31 